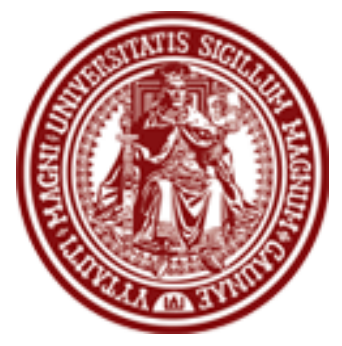

BALTIC JOURNAL OF LAW \& POLITICS

VOLUME 7, NUMBER 1 (2014)

ISSN 2029-0454

http://www.degruyter.com/view/j/bjlp

Cit.: Baltic Journal of Law \& Politics 7:1 (2014): 113-127

DOI: $10.2478 / \mathrm{bjlp}-2014-0007$

\title{
UNIFICATION OF JUDICIAL PRACTICE CONCERNING PARENTAL RESPONSIBILITY IN THE EUROPEAN UNION - CHALLENGES APPLYING REGULATION BRUSSELS II BIS
}

\author{
Kristina Pranevičienè \\ Lecturer; Dr. \\ Mykolas Romeris University, Faculty of Public Security, Department of Law \\ (Lithuania) \\ Contact information \\ Address: V. Putvinskio st. 70, LT-44211 Kaunas, Lithuania \\ Phone: +370 37303655 \\ E-mail address: kristina.praneviciene@gmail.com
}

Received: May 11, 2014; reviews: 2; accepted: June 30, 2014.

\begin{abstract}
The article briefly describes international legislation in parental responsibility matters and focuses on the Council Regulation (EC) No 2201/2003 of 27 November 2003 concerning jurisdiction and the recognition and enforcement of judgments in matrimonial matters and the matters of parental responsibility, repealing Regulation (EC) No 1347/2000 (in practice called Brussels II a or Brussels II bis). The essay reveals and analyses the difficulties which occur while hearing parental responsibility cases within the European Union. Particular attention is given to special cases which were difficult to resolve for the national courts of the Republic of Lithuania. Also, the practice of the Court of Justice of the European Union is examined. The guidelines on how to avoid the problems of establishing jurisdiction are given. The relations of 1980 Hague Convention on international child abduction and Regulations Brussels II bis are revealed and the reasons for adoption of the Regulation are highlighted. The article also proposes improvements for Article 15 of the Regulation and the effective application of a modified forum non conveniens doctrine in parental responsibility cases.
\end{abstract}




\section{KEYWORDS}

Brussels II a, Brussels II bis, 1980 Hague Convention on international child abduction, jurisdiction, parental responsibility, child abduction 


\section{INTRODUCTION}

Nowadays globalization inevitably affects our lives. We can hardly talk about a static model of a state. A concept of a state is influenced by the necessity to properly establish its functions in the era of globalization. Many issues cross the borders of one state, and therefore states have to be versatile enough to protect the individuals who are in their jurisdiction. ${ }^{1}$ Thus globalization of law is unavoidable.

The principle of the free movement of persons presupposes the opportunity to travel freely throughout Europe and has enabled European citizens to live and work in other European Member States without any special permission or visa. This process of integration determined the increase in the number of international families. Unfortunately, international marriages sometimes end up in international divorces. ${ }^{2}$ This fact presupposes that international collisions of jurisdiction occur. International divorce is very complicated, long and sensitively affects children.

The establishment of jurisdiction is one of the first and main issues that has to be dealt with by the court before hearing a case itself. As the practice has shown lately, the number of international parental responsibility disputes is increasing. ${ }^{3}$ Moreover, parental rights and duties often become only the means to an end while the battle for a child is waged. One frequently forgets that in most cases the mere results of such a battle are only the trampled rights and interests of the child. Therefore, the last few decades were very important in the harmonization of laws concerning the protection of children rights and family matters in Europe and worldwide. As Margaret Thatcher once figuratively put it: "parenthood is for life". This phrase accurately reflects the essence of parental responsibility matters in modern society. Parents are those persons who have the greatest influence and authority towards the growing children. A child's best interests must always be of the utmost importance while dealing with parental responsibility issues.

\footnotetext{
1 Irmantas Jarukaitis, Europos Sajunga ir Lietuvos Respublika: konstituciniai narystès pagrindai (European Union and the Republic of Lithuania: constitutional elements of the membership) (Vilnius, Justitia, 2011), p. 43.

${ }^{2}$ According to the figures, about 170000 international marriages contracted in the European Union end up by divorce. A. Fiorini, "Rome III Choice of Law in Divorce: is the Europeanization of Family Law Going Too Far?" International Journal of Law, Policy and the Family 22 (2008): 178.

3 Parental responsibility is the hinge of all family cases that reach the Court of Justice of the European Union.
} 


\section{THE LEGAL REGULATION OF PARENTAL RESPONSIBILITY MATTERS IN THE EUROPEAN UNION AND WORLDWIDE}

In the frames of the Hague Conference on Private International Law several conventions were adopted in the sphere of protection of the rights of a child (Convention of 5 October 1961 concerning the powers of authorities and the law applicable in respect of the protection of infants, Convention of 25 October 1980 on the Civil Aspects of International Child Abduction, Convention of 19 October 1996 on Jurisdiction, Applicable Law, Recognition, Enforcement and Co-operation in Respect of Parental Responsibility and Measures for the Protection of Children). The 1989 United Nations Convention on the Rights of a Child also has special significance. International parental responsibility matters are touched upon for the first time in these documents. The international endeavour to unify the means of solving parental responsibility issues encouraged the European Union to take means to guarantee the effective hearing of parental responsibility cases within the Union as well. The first document concerned with marital issues was the Brussels Convention of 28 May 1998 on jurisdiction and recognition and enforcement of courts judgements in cases related to marriage (so called Brussels II Convention). However, the Treaty of Amsterdam in affect from 1 May 1999, suspended the enactment of the Brussels II Convention. According to the Treaty of Amsterdam the Institutions of the European Union obtained competence to regulate European Civil Procedure directly. In 1999 the Tampere European Council in as many words expressed the will to create an area of freedom, security and justice. The Hague programme of 2005-2010 identified as a priority the mutual trust and encouraged the European Union to take determined steps in the sphere of family law. The European Commission was urged to give proposals on the issues of maintenance, marital property and divorce. Ultimately, the Stockholm programme of 2010-2014 provided the transformation of mutual trust proceedings into the enforcement of courts judgements without exequatur. Moreover, the free movement of courts judgements (apart from the free movement of persons, capital, goods and services) must be the fifth freedom of the common market. ${ }^{4}$ The free movement of the courts' decisions was one of more important arguments why the drafters of the Regulation decided to supplement the sphere of 1980 Hague Convention which already regulated some issues regarding children abduction. The enforcement of a judgement without exequatur enables the securing of absolute freedom of movement for courts' decisions. Eventually, Brussels II Convention was

\footnotetext{
${ }^{4}$ Mirela Župan, "EU Enforcement Mechanisms Serving the Best Interest of a Child," Presentation in the conference "Enforcement of courts decisions as a condition for an effective judicial protection" which was held on 24-25 of October 2013 in the Ministry of Justice of the Republic of Lithuania.
} 
transformed into a Council Regulation of 29 May 2000, No. 1347/2000 on the jurisdiction, recognition and enforcement of judgments in matrimonial matters (Regulation Brussels II) ${ }^{5}$. The text of the Convention was not considerably modified while transforming it into Regulation ${ }^{6}$. Thus for the first time in the history of European Union decisive actions were taken for establishing harmonised rules for solving family disputes. Regulation Brussels II became effective from 1 of March 2001. Even though parental responsibility issues were intended to be secondary issues near marital issues which occupied the first place in the Regulation, when the Regulation was applied, the Pandora's box had been opened. ${ }^{7}$

One problem emerged immediately: children born out of wedlock and children who are not mutual to both parents remained out of the Regulation sphere. France addressed this issue on 3 July 2000, before the Regulation came into force and suggested to rectify it. ${ }^{8}$ The gap was filled with a new Regulation No. 2201/2003 that was adopted on 27 November 2003. This Regulation in practice is shortened as Brussels II a or Brussels II bis and is applied to all children no matter if they are mutual to both parents or not.

\section{DIFFICULTIES WHILE HEARING PARENTAL RESPONSIBILITY CASES} IN THE EUROPEAN UNION

The rules of jurisdiction that are established in the Regulation Brussels II bis (Articles 8-15) are applied successfully in the courts of the Members States of the European Union. However, sometimes courts face difficulties and the practice of the Court of Justice of the European Union is that cynosure which explains how to properly apply the provisions of the Regulation Brussels II bis.

One of the harshest mistakes which still occasionally occurs in the practice of national courts of the Member States of the European Union is the avoidance of application of directly applicable act - Regulation Brussels II bis even if a parental responsibility case is apparently not national but has a European element. Even if Lithuania has already celebrated its decade anniversary as a member of the European Union, there are cases when national courts apply national rules of civil procedure instead of the Regulation Brussels II bis. For example Kaunas Regional Court in the ruling No. 2S-664-601/2011 of 15 February 2011 examined issues of parental responsibility. The child was practically in Ireland with its mother. Even the

${ }^{5}$ Council Regulation of 29 May 2000, No. 1347/2000 on the jurisdiction, recognition and enforcement of judgments in matrimonial matters, OJ, L 160, 2000.

${ }^{6}$ Katharina Boele-Woelki and Cristina Gonzalez Beilfuss, Brussels II bis: Its Impact and Application in Member States (Antwerpen - Oxford: Intersentia, 2007), p. 5.

7 Stéphanie Francq, "Parental Responsibility under 'Brussels II', "ERA Forum, Volume 4, Issue 1 (2003): 54.

8 Thomas Rauscher, Europäisches Zivilprozeßrecht. Kommentar. 2. Auflage. Band 1 (München: Sellier, European Law Publishers GmbH, 2006). Erwägungsgründe, Einl Brüssel IIa-VO 2. 
fact that a child lives in a different Member State indicated that the case has a European element. Unfortunately, the court applied Article 2.14 of the Civil Code of the Republic of Lithuania (not the provisions of the Regulation!) and stated that the habitual residence of a child is the same as the habitual residence of its parents or guardians. Such argumentation is incorrect for several reasons. First of all, the habitual residence of a child who is brought to the foreign Member State is an autonomous concept and has to be interpreted according to the practice of the Court of Justice of the European Union and not according to the national legal norms. The habitual residence of a child is a place where a child factually lives and is determined at the moment when a court is seized. It is important to note that the translation of Article 8 of the Regulation into Lithuanian language is inaccurate. The moment at which the habitual residence of a child should be defined is a moment of seizing of a court and not a moment when a case (an application) reaches the court. This moment is to be interpreted in the connection with Article 16 of the Regulation. In the authentic texts of the Regulation in English or German the moment of seizing is exactly the moment at which the habitual residence of a child is defined. According to the Article 16, a court shall be deemed to be seized at the time when the document instituting the proceedings or an equivalent document is lodged with the court, provided that the applicant has not subsequently failed to take the steps he was required to take to have service effected on the respondent; or if the document has to be served before being lodged with the court, at the time when it is received by the authority responsible for service, provided that the applicant has not subsequently failed to take the steps he was required to take to have the document lodged with the court. Therefore, a seizing of a court will be the moment of registering an application at the court or a moment when such document is sent electronically. In Mercredi ${ }^{9}$ case the Court of Justice of the European Union stated that seizing of a court via telephone is not a proper seizing of a court in the frames of Article 16 and noted that a seizing of a court could be stated only when an application is given to the court and the applicant has taken steps he was required to take to have service effected on the respondent.

In cases $A^{10}$ and Mercredi ${ }^{11}$ the Court of Justice of the European Union has formulated the criterions that are important while determining the habitual residence of a child. When defining this place, it is important to take into account the duration of the presence of a child at a place, regularity, the reasons and motives of the movement to that place, family and social relations, the nationality of a child, language knowledge, the place of the attendance of school or

\footnotetext{
${ }^{9}$ Barbara Mercredi v. Richard Chaffe, Court of Justice of the European Union (2010, No. C-497/10 PPU).

${ }^{10} A$, Court of Justice of the European Union (2009, No. C-523/07).

${ }^{11}$ Barbara Mercredi v. Richard Chaffe, supra note 9.
} 
kindergarten. Therefore, a national court that is seized will always have the discretion to judge where the habitual residence of a child is, and this issue does not depend on the will of a claimant or defendant. After the analysis of the above mentioned case it is obvious that the case has European element. Moreover, the return procedure of an abducted child was already initiated in Ireland by the father. Still the national court justifies its jurisdiction under the national provisions of the Code of Civil Procedure of the Republic of Lithuania ${ }^{12}$ (Articles 784-785). Court of Justice of the European Union in the Lopez ${ }^{13}$ case strictly stated that a court of a Member State cannot base its jurisdiction to hear a case under the national rules of civil procedure if the rules that are established in the Regulation must be applied or even if the court does not have jurisdiction under the Regulation but the jurisdiction under Brussels II bis belongs to another Member State's court. All in all, only if no court has jurisdiction under the rules of Regulation Brussels II bis, can the jurisdiction be established under national civil procedure rules. A similar case was also in Estonia - after Estonia's accession to the European Union a directly applicable act (Regulation Brussels II bis) was not applied and national rules were chosen instead. Despite several training programmes for judges the aims of the Regulation are not yet in the legal minds of judges. ${ }^{14}$ We can comfort ourselves that we are not the only ones who make mistakes but it brings no honour.

The best panacea to solve the abovementioned problem is to apply the three steps tests: first of all, if a court gets a European parental responsibility case it should check if it has jurisdiction to hear it according to the provisions of the Regulation; second, if not, a court must check if any court of another Member State of the European Union has jurisdiction to hear a case according to the Regulation; third, if jurisdiction cannot be established under the provisions of the Regulation Brussels II bis, only then can a court apply national rules of civil procedure. The application of this test should help to avoid mistakes establishing jurisdiction and to evade jurisdiction collisions.

It is commendable that the practice of the Court of Appeal while defining the habitual residence of a child is good. For instance, in case E.R. V. T.S. and T.S., Court of Appeal stated that "a child has acquired the habitual residence in Poland, while living there constantly, and the applicant knew about the presence of a child in that place but did not give an application to return a child within the period of

\footnotetext{
${ }^{12}$ Code of Civil Procedure of the Republic of Lithuania, Official Gazette, 2002, no. 36-1340.

${ }^{13}$ Kerstin Sundelind Lopez v. Miguel Enrique Lopez Lizazo, Court of Justice of the European Union (2007, No. C-68/07), para 18-28.

${ }^{14}$ Katharina Boele-Woelki and Cristina Gonzalez Beilfuss, supra note 6, p. 84.
} 
one year, i.e. practically approved the retain of a child. Therefore, the jurisdiction of a case of a child return belongs to the courts of the Republic of Poland."15

A problem can occur in practice if the habitual residence of a child suddenly changes when a case is already being heard. We suggest that then the principle of perpetuatio fori operate and the court retains its jurisdiction to hear a case. A more complicated situation can occur if a court is being seized in a country where a child has not already acquired habitual residence. In this case the court should leave the application untried because it has no jurisdiction under Article 8 of the Regulation.

The 1980 Hague Convention is applied together with the Regulation if a case is related to wrongful removal or retention of a child within the European Union Member States (except for Denmark for which the Regulation is not applied). The sphere of the Convention is constricted and specific - it is a means to secure a safe and quick return of the child and to secure parents' rights to see the child and communicate with him/her. The cornerstone principal that is established in the Regulation Brussels II bis that Regulation does not replace the 1980 Hague Convention but supplements its regulation sphere ${ }^{16}$ and establishes the preference of the Regulation over the Hague Convention of 1980 in cases when Regulation has special rules. The Institutions of the European Union have not only admitted that the provisions of the Convention do not need to be improved but also have consolidated the application of the Convention to the legal system of the European Union ${ }^{17}$. Despite the fact that all European Member States have ratified the 1980 Hague Convention, it was rather easy to use the exceptions that are established in the Convention to legitimize the wrongful removal and stay of a child in a different Member State than the State of origin (according to the statistics in the year 2000 more than half of the cases were refused to return a child to its state of origin while using an exceptions of the 1980 Hague Convention ${ }^{18}$ ). Therefore, steps were determined that were essential to take that could prevent wrongful removals and retentions of children - to establish stricter rules in the Regulation (though, there were contradictory opinions in Europe ${ }^{19}$ ).

\footnotetext{
${ }^{15}$ E.R. v. T.S. and T.S., Court of Appeal of the Republic of Lithuania (2006, No. 2-568/2006).

${ }^{16}$ Dieter Martiny, "Hague Conventions in Private International Law and on International Civil Procedure"; in: Max Planck Encyclopaedia of Public International Law, Vol. 4. (Oxford University Press, 2012).

17 Paul R. Beaumont and Peter E. McEleavy, The Hague Convention on International Child Abduction (Oxford University Press, 2004), p. 225.

18 Peter McEleavy, "Brussels II bis: Matrimonial Matters, Parental Responsibility, Child Abduction and Mutual Recognition," International and Comparative Law Quarterly Vol. 53, Issue 2 (April 2004): 505.

${ }^{19}$ Katarina Trimmings, Children Abduction Within the European Union, Studies in Private International Law (Hart Publishing, 2013), p. 20-21; Peter Ripley, "A Defence of the Established Approach to the Grave Risk Exception in the Hague Child Abduction Convention," Journal of Private International Law Vol. 4, No. 3 (December 2008): 445; Paul R. Beaumont and Lara Walker, "Shifting the Balance Achieved by the Abduction Convention: the Contrasting Approaches of the European Court of Human Rights and the European Court of Justice," Journal of Private International Law Vol. 7, No. 2 (August 2011): 249.
} 
When the Regulation does not cover particular issues the 1980 Hague Convention is applied. Scholars ${ }^{20}$ emphasise that such complement of the regulation sphere of the Convention should not dwarf the main fact that essential political change occurred which reflects while analysing Articles 17-18 of the Preamble of the Regulation. First of all, the status quo ante must be secured - an abducted child should be returned to its state of origin immediately and the priority for such return is given every time. In the following way the best interests of a child are secured, the guardian rights are protected and the jurisdiction of the court of the state of origin is respected. Quick return of a child helps to secure that a child will not integrate in the new environment. It was one of the main aims of the drafters of the Convention while seeking to solve child abduction problem. Secondly, the rulings of the courts of the state of origin will always say the last word about the return of a child. Furthermore, the supplement of the sphere of the Convention with the provisions of the directly applicable Regulation ensured that in children abduction cases the enforcement mechanism without exequatur will work effectively and this will let to proceed with enforcement of judgements immediately. However, as the practice has shown the systemic application of the Regulation and 1980 Hague Convention is a complicated and sophisticated process and requires special, complex legal skills.

Another national case that reveals the relation between the Regulation Brussels II bis and the 1980 Hague Convention on international child abduction is related to the return of an abducted child from the Republic of Lithuania to the United Kingdom. The daughter of an applicant mother had acquired a habitual residence in the United Kingdom because she had lived there for seven years. The father of the girl wrongfully brought the daughter to the Republic of Lithuania without the mother's knowledge. The mother applied to the Vilnius Regional Court asking to return the child to the United Kingdom. The court refused to return the child and the Court of Appeal also stated the same but with different arguments. According to the Court of Appeal of the Republic of Lithuania, the main reason for the non-return order was the child's adaptation to the new environment. Such a factor allows for the application of Article 12 of the 1980 Hague Convention but with the strict condition that a term of one year has to be passed at the day of the commencement of the proceedings. However, the Court of Appeal avoided applying the term of one year and considered this criterion as "procedural and formal, not corresponding to the real situation in particular case". Such argumentation is controversial. A wrongful retention of the child protracted because of the long

${ }^{20}$ Ulrich Magnus, et al., Brussels II bis Regulation (Munich: Sellier European Law Publishers, 2012), p. 129. 
hearing of the case in an appeal. Article 11.3 of the Regulation Brussels II bis oblige to act expeditiously in proceedings on the application, using the most expeditious procedures available in national law. The court shall, except where exceptional circumstances make this impossible, issue its judgment no later than six weeks after the application is lodged. Meanwhile, in the abovementioned case the procedure in the first instance took about two months and in the appeal procedure the expertise of a child was appointed which prolonged the process for more than ten months. ${ }^{21}$ It is little wonder that during the period of hearing the case the girl adapted to the new environment. However, the fact of adaptation cannot by itself determine the reasons to award a non-return ruling because such interpretation is contrary to the Article 12 of 1980 Hague Convention and Article 11.3 of Brussels II bis Regulation (interpretation contra legem). The sequence of events went as it was possible to predict: the court of the United Kingdom (state of origin) gave a ruling 22 to return the child to the United Kingdom according to the Article 11.8 of the Brussels II bis Regulation (notwithstanding a judgment of non-return pursuant to the 1980 Hague Convention, any subsequent judgment which requires the return of the child issued by a court having jurisdiction under this Regulation shall be enforceable in accordance with Section 4 of Chapter III of the Regulation in order to secure the return of the child). Notwithstanding the ruling was given in September 2013 and it contained a date of enforcement and the certificate was issued, the father of the girl gave all his effort for the ruling not to be executed. A certificate permits the enforcement of the ruling in the Republic of Lithuania without recognition procedure (without exequatur). A certificate is an enforceable document according to the Law of the Republic of Lithuania which implements the European Union and International legal acts that regulate international civil procedure ${ }^{23}$ (Article 9.2). If Lithuanian institutions are powerless to ensure the proper enforcement of the ruling that is confirmed by a certificate, the situation can roll into a case against Lithuania in the European Court of Human Rights (a similar case is Ignaccolo Zenide v. Romania) ${ }^{24}$.

With respect to the rapidity of an abducted child return process, it is worth noting that in general Lithuanian civil procedure allows very good prerequisites for a child abduction case to be solved very quickly. European case of child abduction is

\footnotetext{
${ }^{21}$ It is to be noted that Western European States cope with these cases more effectively. For example, in the year of 2012 four judgements in the United Kingdom were awarded within two months after the application, three judgements - within three months and one judgement within one month. France awarded a judgement of the return of a child within five months (Official information of the State Child Rights Protection and Adoption Service under the Ministry of Social Security and Labour // http://www.vaikoteises.It (accessed May 29, 2014)).

22 L.A. v. S. A., United Kingdom High Court of Justice, Family Division (2013, no. FD13P00646).

${ }^{23}$ Law of the Republic of Lithuania which implements the European Union and international legal acts that regulate international civil procedure, Official Gazette (2008, no. 137-5366).

${ }^{24}$ Ignaccolo Zenide v. Romania, European Court of Human Rights (2000, no. 31679/96).
} 
heard according to the Chapter XXXIX of Lithuanian Code of Civil Procedure if Regulation Brussels II bis, 1980 Hague Convention or Law of the Republic of Lithuania which implements the European Union and International legal acts that regulate international civil procedure do not establish any special rules. Generally, rules that regulate a summary procedure are applied. Application that is given to a court must be heard within five working days from the date it was given. ${ }^{25}$ According to the times defined, person's legal expectation that a child return process will proceed quickly is realistic but courts have to follow the terms strictly.

\section{FORUM NON CONVENIENS - A CONSENSUS OF THE COMMON LAW SYSTEM AND THE CONTINENTAL LEGAL SYSTEM WHICH IS TO BE IMPROVED}

One of the greatest innovations in European civil procedure is a modified version of the forum non conveniens doctrine that is established in Article 15 of the Brussels II bis Regulation. It should be noted that this Article does not permit the rejection of jurisdiction ex-parte but allows a court first seized to transfer jurisdiction while co-operating with one of the parties or with a court of another Member State which is eager to hear a case. ${ }^{26}$ The doctrine of forum non conveniens is an exception to the principle of perpetuatio fori in the Regulation because a case can be transferred within the Member States of the European Union and only if all the conditions of Article 15 are fulfilled. Besides, Article 15 of Brussels IIbis Regulation is in absolute distinction to the Regulation Brussels Ibis which does not implicate forum non conveniens in it. A consensus of establishing forum non conveniens in Brussels II bis Regulation for parental responsibility cases was accepted because it was agreed that superior interests of a child are utmost important aim in these cases. This was one of the most important reasons why continental legal systems agreed to accept a doctrine which was developed in the common law legal system. In the United Kingdom the forum non conveniens is a commonly applied doctrine, while, for example, in German national civil procedure the doctrine of forum non convenience is not applied at all. ${ }^{27}$ In Greece or Spain, for instance, there are no rules and legal norms which could let the application of forum non conveniens. ${ }^{28}$ Because of the divergences of the different legal systems the courts of the Member States of the European Union are not eager to apply this doctrine in practice and no efficiency is reached with such legal regulation.

\footnotetext{
${ }^{25}$ Lithuanian Code of Civil Procedure, supra note 12, art. 582.2.

26 Thomas Rauscher, supra note 8, p. 934.

27 Thalia Kruger, Civil Jurisdiction Rules of the European Union and their Impact on Third States (Oxford University Press, 2008), p. 282.

${ }^{28}$ Katharina Boele-Woelki and Cristina Gonzalez Beilfuss, supra note 6, p. 142, 292.
} 
Moreover, difficulties arise because the legal norms and wording of Article 15 are insufficient and this Article should be improved when reviewing the Regulation text. Although parts 4 and 5 of Article 15 regulate precisely how a case can be transferred with an initiative of a court seized or an initiative of one party, but these rules do not cover cases when a case can be transferred with an initiative of a court of another Member State to which a child is related. This can lead to difficulties in practice applying Article 15. It would be expedient to supplement the provisions of Article 15 and, to put it logically, how a takeover of jurisdiction should follow if a court of another Member State is a better place to hear a case. An effective security of the aims of Regulation can be reached firstly if courts cooperate directly. In practice it should proceed in the most expeditious ways: via telephone, or email. For the purpose of defining the framework and term for the transfer of a case it is essential to determine the period which would be enough to decide that a transfer is needed. According to the analogy of part 5 of Article 15, it would be wise and rational to establish a period of six weeks, which is enough to decide about a transfer. Conclusively, we do suggest to supplement Article 15 with part 6 and the present part 6 to consider as part 7 while arranging part 6 as follows: "When a court of the other Member State, with which the child has a particular connection in accordance with paragraph 3, decides that it is a better placed to hear a case and for the particular circumstances this is in the best interests of a child, it has a right at first directly or, if necessary through central authorities, apply to the court first seized for the transfer of jurisdiction. A court first seized announce the decision to transfer a case within 6 weeks from the reception of an application to transfer a case."

What is more, one reference for a preliminary ruling is already pending ${ }^{29}$ in the Court of Justice of the European Union and the judgment of CJEU should give guidelines for the proper interpretation and application of this Article as well.

\section{CONCLUSIONS}

International endeavours and the adopted Hague Conventions on child's rights protection have encouraged the European Union to also take determined steps to guarantee the effective hearing of parental responsibility cases within the Member States. The application of the Regulation Brussels II bis and 1980 Hague Convention requires a lot of complex legal skills and practice. Those who apply these legal instruments must always take into account the case law of the Court of Justice of the European Union and its legal doctrine.

${ }^{29}$ E. v. B., Court of Appeal (England \& Wales) (Civil Division) (2013, no. C-436/13). 
We do suggest the application of the three steps tests: first, if a court gets a European parental responsibility case it should check if it has jurisdiction to hear it according to the provisions of the Regulation; second, if not, the court must check if any other court of another Member State of the European Union has jurisdiction to hear a case according to the Regulation; third, if jurisdiction cannot be established under the provisions of the Regulation Brussels II bis, only then can a court apply national rules of civil procedure. The application of this test should help to avoid mistakes establishing jurisdiction and to evade jurisdiction collisions.

A consensus of a modified version of forum non conveniens doctrine was accepted in the Brussels II bis system mainly because it was agreed upon that the superior interests of the child are the most important aim in these cases. Nevertheless, for the proper application of Article 15, its provisions should be improved as suggested.

\section{BIBLIOGRAPHY}

1. Beaumont, Paul. R., and Lara Walker. "Shifting the Balance Achieved by the Abduction Convention: the Contrasting Approaches of the European Court of Human Rights and the European Court of Justice." Journal of Private International Law Vol. 7, No. 2 (August, 2011): 231-249.

2. Beaumont, Paul R., and Peter E. McEleavy. The Hague Convention on International Child Abduction. Oxford University Press, 2004.

3. Boele-Woelki, Katharina, and Cristina Gonzalez Beilfuss. Brussels II bis: Its Impact and Application in Member States. Antwerpen - Oxford: Intersentia, 2007.

4. Fiorini, A. "Rome III Choice of Law in Divorce: is the Europeanization of Family Law Going Too Far?" International Journal of Law, Policy and the Family No. 22 (2008): 178-205.

5. Francq, Stéphanie. "Parental Responsibility under 'Brussels II'." ERA Forum, Volume 4, Issue 1 (2003): 54-72.

6. Jarukaitis, Irmantas. Europos Sajunga ir Lietuvos Respublika: konstituciniai narystès pagrindai (European Union and the Republic of Lithuania: constitutional elements of the membership). Vilnius: Justitia, 2011.

7. Kruger, Thalia. Civil Jurisdiction Rules of the European Union and their Impact on Third States. Oxford University Press, 2008.

8. Magnus, Ulrich, et al. Brussels II bis Regulation. Munich: Sellier European Law Publishers, 2012. 
9. Martiny, Dieter. "Hague Conventions in Private International Law and on International Civil Procedure": 682-683. In: Max Planck Encyclopedia of Public International Law. Vol. 4. Oxford University Press, 2012.

10. McEleavy, Peter. "Brussels II bis: Matrimonial Matters, Parental Responsibility, Child Abduction and Mutual Recognition." International and Comparative Law Quarterly Vol. 53, Issue 2 (April 2004): 503-512.

11. Official information of the State Child Rights Protection and Adoption Service under the Ministry of Social Security and Labour // http://www.vaikoteises.It (accessed May 29, 2014).

12. Rauscher, Thomas. Europäisches Zivilprozeßrecht. Kommentar. 2. Auflage. Band 1. München: Sellier, European Law Publishers GmbH, 2006.

13. Ripley, Peter. "A Defence of the Established Approach to the Grave Risk Exception in the Hague Child Abduction Convention." Journal of Private International Law Vol. 4, No. 3 (December, 2008): 443-477.

14. Trimmings, Katarina. Children Abduction Within the European Union. Studies in Private International Law. Hart Publishing, 2013.

15. Župan, Mirela. "EU Enforcement Mechanisms Serving the Best Interest of a Child." Presentation in the conference "Enforcement of courts decisions as a condition for an effective judicial protection" which was held on 24-25 of October 2013 in the Ministry of Justice of the Republic of Lithuania.

\section{LEGAL REFERENCES}

1. A. Court of Justice of the European Union, 2009, no. C-523/07.

2. Barbara Mercredi v. Richard Chaffe. Court of Justice of the European Union, 2010, no. C-497/10 PPU.

3. Code of Civil Procedure of the Republic of Lithuania. Official Gazette, 2002, no. $36-1340$.

4. Council Regulation of 23 November 2003, No. 2201/2003 on jurisdiction, recognition and enforcement in matrimonial matters and the matters of parental responsibility, replacing Regulation (EC) No. 1347/2000. OJ, L 338, 2003.

5. Council Regulation of 29 May 2000, No. 1347/2000 on the jurisdiction, recognition and enforcement of judgments in matrimonial matters. OJ, L 160, 2000.

6. E. v. B. Court of Appeal (England \& Wales) (Civil Division), 2013, no. C$436 / 13$. 
7. E.R. v. T.S. and T.S. Court of Appeal of the Republic of Lithuania, 2006, no. 2-568/2006.

8. Ignaccolo Zenide v. Romania. European Court of Human Rights, 2000, no. $31679 / 96$.

9. Kerstin Sundelind Lopez v. Miguel Enrique Lopez Lizazo. Court of Justice of the European Union, 2007, no. C-68/07.

10. L.A. v. S. A. United Kingdom High Court of Justice, Family Division, 2013, no. FD13P00646.

11. Law of the Republic of Lithuania which implements the European Union and international legal acts that regulate international civil procedure. Official Gazette, 2008, no. 137-5366. 